\title{
Neoproterozoic reworking of the Palaeoproterozoic Capricorn Orogen of Western Australia and implications for the amalgamation of Rodinia
}

Sandra A. Occhipinti ${ }^{1,2}$ \& Steven M. Reddy ${ }^{1}$ *

${ }^{1}$ The Institute for Geoscience Research, Dept of Applied Geology, Curtin University of Technology, GPO Box U1987, Perth, WA 6845, Australia

${ }^{2}$ Now at: Fugro Airborne Surveys, Locked Bag 6, Wembley, WA 6014, Australia

* Corresponding author.

E-mail address: S.Reddy@curtin.edu.au

fax: +61-8-9266-3153

Tel.:+61-8-9266-4371

Abbreviated Title: Neoproterozoic reworking of the Capricorn Orogen 


\begin{abstract}
Argon isotopic data from mica from the southern Capricorn region of Western Australia record complex intra- and inter- grain systematics that reflect modification due to a range of processes. However, ${ }^{40} \mathrm{Ar} /{ }^{39} \mathrm{Ar}$ age distributions, though complex, generally show early Neoproterozoic ages in the west, increasing to Mesoproterozoic ages in the east.

Palaeoproterozoic ages associated with cooling after the $c .1 .8 \mathrm{Ga}$ Capricorn Orogen or c.1.6 Ga Mangaroon Orogen are not preserved. These data reflect cooling from a $\sim 300^{\circ} \mathrm{C}$ thermal overprint that took place prior to 960 Ma that is related to the enigmatic Edmunian Orogeny. These data, combined with sediment provenance data from the Early Neoproterozoic Officer Basin and U-Pb age data from the nearby Pinjarra Orogen, indicate that the late Mesoproterozoic - Neoproterozoic Pinjarra and Edmundian events are dynamically linked and reflect tectonic activity on the western margin of the amalgamated West Australian Craton. The temporal framework for this event suggest a link to the evolving Rodinian supercontinent and reflect the oblique collision of either Greater India or Kalahari cratons with the West Australian Craton. These results illustrate that the temporal evolution of poorly preserved orogens can be constrained by low-temperature thermochronology in the adjacent cratons.
\end{abstract}


The cratonic cores of continental interiors are commonly typified by ancient high-grade metamorphic rocks that have seen little tectonic activity since the Archaean. In contrast, the margins of these cratons often record a complex geological evolution involving cycles of rifting, accretion and collision due to the global reorganisation of continental fragments during the repeated dispersal and amalgamation of supercontinents. Geological analysis of craton margins therefore provides a valuable means of constraining ancient supercontinent cycles. However, processes such as continental rifting, subduction erosion and crustal reworking that may take place at cratonic margins can mask or destroy the evidence of earlier tectonic activity; thereby limiting the ability of such areas to successfully assist in the reconstruction of tectonic histories and palaeogeography. An alternative approach is to attempt to identify and characterise the far-field effects of craton margin tectonism within the craton, and use these data to constrain the temporal evolution of processes taking place at the margin. This approach is highlighted by presenting mica ${ }^{40} \mathrm{Ar} /{ }^{39} \mathrm{Ar}$ data from the Palaeoproterozoic Capricorn Orogen of West Australia to provide temporal constraints on tectonic activity along the western margin of the West Australian Craton during the formation of Rodinia.

\section{Geological background}

The West Australian Craton comprises the Archaean Pilbara and Yilgarn cratonic blocks and a series of tectonically complex basement rocks and basins of the Palaeoproterozoic Capricorn Orogen (Myers 1993) (Fig. 1). To the south, the West Australian Craton passes into the Albany-Fraser Belt, a complex series of high-grade metamorphic rocks that were strongly deformed during the Mesoproterozoic collision of the West Australian Craton with the South Australian - East Antarctic continent (Clark et al. 2000). The eastern margin of the West Australian Craton is overlain and completely hidden by sediments of the Proterozoic Officer Basin, the Phanerozoic Canning Basin and the Tertiary Eucla Basin (Trendall and Cockbain 1990). The geological evolution of the western margin of the West Australian Craton is also enigmatic because basin formation associated with the rifting and dispersal of Australia and Greater India during the Cretaceous break-up of Gondwana (Song and Cawood 2000) masks the earlier history. Despite this, the presence of Mesoproterozoic and Neoproterozoic rocks of the Pinjarra Orogen (Fig. 1) attests to an eventful geological evolution of the western margin 
of the craton (Myers 1990; Fitzsimons 2003) following its amalgamation in the Palaeoproterozoic era.

The Capricorn Orogen lies between the Archaean Pilbara and Yilgarn cratons and contains a series of terranes that comprise early to late Archaean granite and granitic gneiss, Palaeoproterozoic metasedimentary and mafic meta-igneous rocks, granite and granitic gneiss (Fig. 1). These units are locally overlain by various sedimentary units deposited in a range of settings between from the Palaeoproterozoic era to the Permian period (see Cawood and Tyler 2004 and references therein).

The Capricorn Orogen comprises rocks deformed and metamorphosed during the 2000 - 1950 Ma Glenburgh Orogeny and the 1830 - 1780 Ma Capricorn Orogeny (Occhipinti et al. 1998; Occhipinti et al. 2004; Sheppard et al. 2004). Mineral assemblages throughout the range of basement rocks in the Capricorn Orogen indicate a regional greenschist facies metamorphic and deformation overprint associated with tectonic activity associated with the latest stages of Capricorn orogenesis (Occhipinti and Reddy 2004; Reddy and Occhipinti 2004; Sheppard et al. 2004). Magmatism, metamorphism and deformation during the $1680-1620 \mathrm{Ma}$ Mangaroon Orogeny is also heterogeneously distributed through the region, becoming more significant to the north (Sheppard et al. 2005).

In the central and eastern parts of the Capricorn Orogen a regionally extensive series of sediments and volcanics (the Bangemall Supergroup) unconformably overlie basement rocks. Dolerite sills that intruded the base of this stratigraphic sequence yield dates of $1465 \pm 3 \mathrm{Ma}$ (Wingate et al. 2002) and $1070 \pm 6 \mathrm{Ma}$ (Wingate et al. 2004). Some of these dykes (of unknown age) were deformed and metamorphosed with the sediments and the underlying basement at low metamorphic grades during the enigmatic Edmundian Orogeny, before being cut by northerly trending dolerite dykes of the 750 Ma Mundine Well dyke swarm (Wingate and Giddings 2000; Martin and Thorne 2004). These overprinting relationships loosely constrain the Edmundian event at 1070-750 Ma.

Despite the relatively well-constrained Palaeoproterozoic evolution of the Capricorn Orogen, there are no published ${ }^{40} \mathrm{Ar} /{ }^{39} \mathrm{Ar}$ data from the orogen. In this paper, the results of a regional ${ }^{40} \mathrm{Ar} /{ }^{39} \mathrm{Ar}$ study document a widespread Late Mesoproterozoic - Neoproterozoic reworking of the Capricorn Orogen. The data, combined with previously published sedimentological data 
from the Officer Basin, and U-Pb zircon data from basement rocks of the Pinjarra Orogen constrain tectonic activity on the western margin of the West Australian Craton.

\section{Analytical Procedure}

A regional suite of samples from different terranes of the Capricorn Orogen and immediately adjacent Yilgarn Craton have been analysed by the ${ }^{40} \mathrm{Ar} /{ }^{39} \mathrm{Ar}$ dating technique. Details of the analysed samples, including sample localities and rock unit descriptions, are given as Supplementary Data. In many cases the analysed samples have an igneous origin and are granitic in composition, though a few samples are amphibolite - granulite facies metasedimentary rocks. In all samples the primary mineralogical assemblage has been retrogressed to greenschist facies metamorphic assemblage (see Supplementary Data). In many cases this reflects the Capricorn Orogeny phase of the tectonic evolution (c.1800Ma) (Occhipinti et al. 2004), although recent studies have illustrated potentially younger metamorphic overprints within the north of the Capricorn region (Sheppard et al. 2005).

Sample preparation and analytical procedure have been described in detail elsewhere (Occhipinti 2004; Reddy et al. 2004) so only a brief summary is presented here. ${ }^{40} \mathrm{Ar} /{ }^{39} \mathrm{Ar}$ analyses were conducted on muscovite and biotite using two different analytical approaches: Infrared laser total grain fusion and infrared laser step-heating. In both cases, samples were crushed and inclusion-free mica grains were selected after examination with a binocular microscope. Depending on grain size, single or multiple grain aliquots were used to ensure sufficient Ar for measurement. All samples were cleaned in methanol, then de-ionised water in an ultrasonic bath. Once dry, the samples were packed in aluminium foil and loaded into an aluminium package with other samples. The package was then Cd-shielded $(0.4 \mathrm{~mm})$ and irradiated in the $\mathrm{H} 5$ position of the McMaster University Reactor, Hamilton, Canada for 90 hours. Biotite age standard Tinto B, with a K-Ar age of 409 Ma (Rex and Guise 1995) was placed at $5 \mathrm{~mm}$ intervals throughout the aluminium package to monitor the neutron flux gradient. Tinto B is a standard that has seen widespread use in the literature (Kelley et al. 1994; Sherlock and Kelley 2002; Reddy et al. 2004; Downes et al. 2006). Correction factors are as follows: $\left({ }^{36} \mathrm{Ar} /{ }^{37} \mathrm{Ar}\right) \mathrm{Ca}=0.000255,\left({ }^{39} \mathrm{Ar} /{ }^{37} \mathrm{Ar}\right) \mathrm{Ca}=0.00065$, and $\left({ }^{40} \mathrm{Ar} /{ }^{39} \mathrm{Ar}\right) \mathrm{K}=$ 0.0015. Corrections for $\left({ }^{38} \mathrm{Ar} /{ }^{39} \mathrm{Ar}\right) \mathrm{K}$ and $\left({ }^{38} \mathrm{Cl} /{ }^{39} \mathrm{Ar}\right) \mathrm{K}$ were not undertaken because of the Proterozoic age and low $\mathrm{Cl}$ characteristics of the samples and the short amount of time between irradiation and the time of analyses. 
Following irradiation, Ar was extracted using a CW-Nd-YAG laser, fired through a Merchantek computer-controlled X-Y-Z sample chamber stage and microscope system. A defocused $200 \mu \mathrm{m}$ beam (9.7-11 Amps for 120 seconds) was used for infrared laser analyses. Data were corrected for mass spectrometer discrimination and nuclear interference reactions. Errors quoted on the ${ }^{40} \mathrm{Ar} /{ }^{39} \mathrm{Ar}$ ages are $1 \sigma$, and ages were calculated using usual decay constants (Steiger and Jager 1977). J values are noted on the supplementary data tables. Background Ar levels were monitored prior to and after each analysis and the mean of the two blanks was used to correct each sample analysis. Ar data were corrected for mass spectrometer discrimination, ${ }^{37} \mathrm{Ar}$ decay, and ${ }^{38} \mathrm{Ar}$ decay.

\section{Results}

Total-fusion data and step-heating age spectra are presented as accompanying supplementary data and are shown in Figs. 4,5 \& 6. The ${ }^{40} \mathrm{Ar} /{ }^{39} \mathrm{Ar}$ data are also summarised in Table 1 and on the regional geological map (Fig. 3). Overall the data show that apparent ${ }^{40} \mathrm{Ar} /{ }^{39} \mathrm{Ar}$ ages measured in biotite are often older than those measured in muscovite from the same samples and the same range of grain sizes (Figs. 4 \& 5). In addition, there is commonly a wide range of ${ }^{40} \mathrm{Ar} /{ }^{39} \mathrm{Ar}$ ages within individual samples. In some cases this is directly correlated to grain size and indicates the potential presence of excess argon, particularly in some of the biotite samples, and heterogeneous Ar loss in others. In all samples, measured ${ }^{36} \mathrm{Ar}$ differs little from background ${ }^{36} \mathrm{Ar}$ levels. As a result, the use of isotope correlation diagrams $\left({ }^{36} \mathrm{Ar} /{ }^{40} \mathrm{Ar}\right.$ vs ${ }^{39} \mathrm{Ar} /{ }^{40} \mathrm{Ar}$ ) is precluded as a means of recognising excess ${ }^{40} \mathrm{Ar}$. A detailed analysis of the complexity recorded at the individual sample level in the ${ }^{40} \mathrm{Ar} /{ }^{39} \mathrm{Ar}$ data has previously been described and analysed in considerable detail with respect to composition (associated with mineral and fluid inclusion contamination), grain size and excess ${ }^{40} \mathrm{Ar}$ and $\mathrm{Ar}$ loss (Occhipinti 2004). A summary of these data and age interpretations derived by Occhipinti (2004), taking these variables into account, are given in Table 1. Readdressing the complexity is beyond the scope of this paper and we focus on the broad patterns that emerge from the data and their tectonic significance.

Age data for the eastern Errabiddy Shear Zone, the western Errabiddy Shear Zone, and the Gascoyne Complex for single and multiple grain total-fusion show a wide range of apparent ${ }^{40} \mathrm{Ar} /{ }^{39} \mathrm{Ar}$ ages that show complex relationships with grain size but define several distinct age 
peaks (Figs. 4 \& 5). By far the biggest peaks, and therefore age distributions, for both muscovite and biotite, are of early Neoproterozoic age (Fig. 5). In detail age variations correspond to different regions. Biotite analysed by infrared total fusion (Fig. 6a) show welldefined peaks between 1650 and 1580 Ma (Eastern Errabiddy Shear Zone, n=10 of 11 analyses), 960 and 880 Ma (Western Errabiddy Shear Zone, $n=40$ of 51 analyses), and 1020 and $930 \mathrm{Ma}$ (Gascoyne complex, n=24 of 38 analyses). Smaller peaks are present between 1270 and 1160 Ma (Western Errabiddy Shear Zone, n=11 of 51 analyses), and older ages up to c. 1350 Ma are recorded from the Gascoyne Complex (n=9). Muscovite total fusion ages between c. 1690 - 880 Ma are recorded for the Eastern Errabiddy Shear Zone, but do not define statistically valid peaks. For the Western Errabiddy Shear Zone, 15 out of 34 ages are between 920 - 880 Ma. This is broadly consistent with the greatest number of ages measured in the Gascoyne Complex between 900 - $870 \mathrm{Ma}$ (n=7 of 11 analyses) (Fig. 5).

Step-heating experiments on both biotite and muscovite yield complex age spectra (Fig.6) that often correlate with compositional (Ca and $\mathrm{Cl}$ ) variations (Occhipinti 2004). Generally the spectra do not record statistically valid plateaux. However, the distribution of Mesoproterozoic and Neoproterozoic ages recorded by total fusion analyses are mimicked in the step-heating data, and, despite the complexity, attest to Neoproterozoic isotopic resetting. It is noticeable that biotite from the Narryer Terrane yields Mesoproterozoic ages that are considerably different to those measured in both the Gascoyne Complex and Errabiddy Shear Zone (Fig 6). However a single muscovite spectrum from the Narryer Terrane also yields Neoproterozoic ages and is similar to ages further north.

\section{Discussion}

Despite complexities in grain size - age relationships (Fig.4) and Ar age - composition spectra (Occhipinti 2004) general patterns in ${ }^{40} \mathrm{Ar} /{ }^{39} \mathrm{Ar}$ age distributions indicate differences in the thermal history of different parts of the orogen at a time substantially postdating the last major orogenic (Palaeoproterozoic) event in the region. The apparent overlap of c. $960-820$ Ma ages in the single-grain fusion and step-heating data from the western Errabiddy Shear Zone and Gascoyne Complex indicate a previously unrecognised isotopic resetting associated with regional heating of the western Capricorn Orogen during the early Neoproterozoic era. The extent of this resetting event $\left(17,000 \mathrm{~km}^{2}\right)$ is significant and indicates a regional, not local, thermal perturbation. Closure temperature models for micas suggest temperatures of 
$350-270^{\circ} \mathrm{C}$ (calculated using a cooling history assumption of $10^{\circ} \mathrm{C} / \mathrm{Ma}$ ) are required to cause this resetting. This temperature range is consistent with the low metamorphic grades seen in Mesoproterozoic sedimentary rocks in the region. Older ages from the Eastern Errabiddy Shear Zone indicate a lesser degree of isotopic resetting but still indicate some Ar isotopic disturbance significantly after the c.1800 Ma greenschist facies metamorphism associated with Palaeoproterozoic Capricorn orogenesis. The pattern of isotopic resetting generally decreases towards the east, indicating that the cause of resetting was more proximal to the west. Mesoproterozoic aged biotites in the Narryer Terrane may also reflect incomplete resetting after the Capricorn event. However, a single muscovite age of 834 Ma may indicate a component of excess ${ }^{40} \mathrm{Ar}$ in the biotite data. New Ar data from the Archaean rocks of the Narryer Terrane to the south of this study area indicates both a Capricorn ( 1750Ma) overprint and a younger, weaker and heterogeneously distributed overprint (Spaggiari et al. 2008).

The Edmundian Orogeny is associated with localised north and east trending folds and faults recorded throughout the Capricorn region, particularly in the Bangemall Supergroup. The age of this deformation event is poorly constrained but has been bracketed by age data on deformed and younger undeformed dolerite dykes that yield ages of $1070 \mathrm{Ma}$ and $750 \mathrm{Ma}$ respectively (Wingate and Giddings 2000; Martin and Thorne 2004; Wingate et al. 2004). The regional causes of Edmundian orogenesis has remained unclear. However, the 960 - 820 Ma age range for regional mica resetting is consistent with an Edmundian thermal perturbation associated with early Neoproterozoic tectonism.

The Neoproterozoic Officer Basin forms part of the Centralian Superbasin (Walter et al. 1995). Palaeocurrent data from the base of the northwestern part of the Officer Basin, the Sunbeam Group, indicates that during the early Neoproterozoic era, sediments were derived from the west (Fig. 7). Sediment characteristics are consistent with sourcing from the eroding Bangemall Supergroup and a rapid increase in sediment supply (Williams 1992) and deposition in non-marine to shallow-marine conditions (Grey et al. 2005). Detrital zircon populations from the Tarcunyah Group of the Officer Basin, immediately north of the Sunbeam Group, also record U-Pb ages consistent with derivation from the Gascoyne Complex (Bagas 2003). Asymmetric sediment dispersion within the Sunbeam Group, coarsening upward successions, and the lack of any active volcanism associated with its development, together support the possibility that the sediments were deposited in an 
intracontinental foreland basin-like setting (Jordan 1995; Miall 1995) with an evolving orogen situated to the west (Williams 1992). Although, alternative interpretations of deposition environment are possible from sedimentological observations (Bagas 2003; Grey et al. 2005), the available data from the age-equivalent parts of the Officer Basin are consistent with Neoproterozoic tectonism localised in the western Capricorn Orogen.

To the west of the amalgamated West Australian Craton, the Pinjarra Orogen (Fig. 1) comprises high grade metamorphic rocks of the Northampton and Mullingarra Complexes in which granulite and amphibolite facies metamorphism has been dated at $1079 \mathrm{Ma}$ and 1058 Ma respectively (Bruguier et al. 1999; Fitzsimons 2003). Zircon provenance data from paragneiss units within these two complexes indicate the Mesoproterozoic Albany-Fraser Orogen as a likely sediment source, and, combined with the limited extent of high-grade metamorphism, has been used to suggest that the Northampton and Mullingarra Complexes are allochtonous and are derived from much further south (Fitzsimons 2003). Mafic dykes that are emplaced both within the Northampton Complex and the Yilgarn Craton, indicate that tectonic juxtaposition of the two complexes with the West Australian Craton must have taken place prior to c. 750Ma (Wingate and Giddings 2000). Consequently, there is some evidence for tectonism within the Pinjarra Orogen between 1080 and 750 Ma (Fitzsimons 2003). From the geometry of the 750 Ma mafic dykes and brittle-ductile northerly trending dextral shear zones that post-date their emplacement (Byrne and Harris 1993), Fitzsimons (2003) argues that dextral transpressional within the Pinjarra Orogen took place around $750 \mathrm{Ma}$. Although broadly consistent with this model, the Ar data presented here indicate much earlier tectonic activity along this western margin of the West Australian Craton.

The coincidence of thermal resetting of Capricorn micas, the provenance of sediments from the Officer Basin and zircon data from the high-grade metamorphic complexes of the Pinjarra Orogen are consistent with tectonic activity along the western margin of the West Australian Craton during the early Neoproterozoic. In this scenario the Pinjarra and Edmundian orogenies are linked in that they represent the local and far-field effects of this tectonism respectively. On a larger scale, this tectonism is likely to represent convergence of continental material with the West Australian Craton during the early Neoproterozoic assembly of the supercontinent Rodinia (Fig. 8). Depending on which Rodinian reconstruction is preferred, either Kalahari or Greater India are potential candidates for collision with the West Australian Craton during the early Neoproterozoic (Pisarevsky et al. 2003; Li et al. 2007). Irrespective 
of which of these may or may not be correct, the isotopic resetting associated with Pinjarra/Edmundian tectonism within the Capricorn Orogen suggests that deformation and metamorphism of the region took place considerably earlier than the $750 \mathrm{Ma}$ minimum age of orogenesis deduced from the earlier studies (Wingate and Giddings 2000; Fitzsimons 2003; Martin and Thorne 2004; Wingate et al. 2004). Consequently, future testing of Rodinian reconstructions requires that early Neoproterozoic tectonism be used for temporal correlation with potential collisional candidates.

\section{Conclusions}

${ }^{40} \mathrm{Ar} /{ }^{39} \mathrm{Ar}$ dating of micas from the Palaeoproterozoic Capricorn Orogen yield cooling ages indicating early Neoproterozoic lower greenschist facies metamorphic conditions of regional extent. Variations in the degree of resetting suggest higher temperatures in the west of the region and point towards the thermal event being associated with tectonic activity on the western margin of the amalgamated West Australian Craton. This interpretation is supported by evidence from the Neoproterozoic Officer Basin and the Pinjarra Orogen. The results indicate the potential of low temperature thermochronology to provide within-craton evidence of far-field tectonic activity that may be poorly preserved at the craton margins. In this case the results suggest a dynamic link between the Pinjarra and Edmundian orogenies associated with collisional orogenesis during the early Neoproterozoic amalgamation of Rodinia.

\section{Acknowledgements}

The authors thank the Australian Research Council (A00106036) for funding this research. The Tectonics Special Research Centre and the Geological Survey of Western Australia, particularly Ian Tyler and Steve Sheppard, are thanked for their support. Pete Betts, Dave Corrigan, Dave Foster and an anonymous reviewer are thanked for their comments on the manuscript. This paper is TIGeR publication 96. 


\section{References}

Bagas, L. 2003. Zircon provenance in the basal part of the northwestern Officer Basin, Western Australia, Western Australia Geological Survey, Annual Review 2002-2003.

Bruguier, O., Bosch, D., Pidgeon, R. T., Byrne, D. I. \& Harris, L. B. 1999. U-Pb chronology of the Northampton Complex, Western Australia - evidence for Grenvillian sedimentation, metamorphism and deformation and geodynamic implications. Contributions to Mineralogy and Petrology, 136, 258-272.

Byrne, D. \& Harris, L. B. 1993. Structural controls on the base-metal vein deposits of the Northampton Complex, Western Australia. Ore Geology Reviews, 8, 89-115.

Cawood, P. A. \& Tyler, I. M. 2004. Assembling and reactivating the Proterozoic Capricorn Orogen: Lithotectonic elements, orogenies, and significance. Precambrian Research, 128, 201-218.

Clark, D. J., Hensen, B. J. \& Kinny, P. D. 2000. Geochronological constraints for a two-stage history of the Albany-Fraser Orogen, Western Australia. Precambrian Research, 102, 155183.

Downes, P. J., Wartho, J. A. \& Griffin, B. J. 2006. Magmatic evolution and ascent history of the Aries Micaceous Kimberlite, central Kimberley Basin, Western Australia: Evidence from zoned phlogopite phenocrysts, and UV laser ${ }^{40} \mathrm{Ar} /{ }^{39} \mathrm{Ar}$ analysis of phlogopite-biotite. Journal of Petrology, 47, 1751.

Fitzsimons, I. C. W. 2003. Proterozoic basement provinces of southern and southwestern Australia, and their correlation with Antarctica. In Yoshida, M., Windley, B. F. \& Dasgupta, S. (eds) Proterozoic East Gondwana: Supercontinent Assembly and Breakup. Geological Society, London, Special Publication, 206, 93-130.

Grey, K., Hocking, R. M., Stevens, M. K., Bagas, L., Carlsen, G. M., Irimies, F., Pirajno, F., Haines, P. W. \& Apak, S. N. 2005. Lithostratigraphic nomenclature of the Officer Basin and correlative parts of the Paterson Orogen, Western Australia, Western Australia Geological Survey Report 93.

Jordan, T. E. 1995. Retroarc foreland and Related Basins. In Busby, C. J. \& Ingersoll, R. V. (eds) Tectonics of Sedimentary Basins. Blackwell Science, 331-362. 
Kelley, S. P., Arnaud, N. O. \& Turner, S. P. 1994. High-spatial-resolution ${ }^{40} \mathrm{Ar} /{ }^{39} \mathrm{Ar}$ investigations using an ultra-violet laser probe extraction technique. Geochimica et Cosmochimica Acta, 58, 3519-3525.

Li, Z. X., Bogdanova, S. V., Collins, A. S., Davidson, A., De Waele, B., Ernst, R. E., Fitzsimons, I. C. W., Fuck, R. A., Gladkochub, D. P., Jacobs, J., Karlstrom, K. E., Lu, S., Natapov, L. M., Pease, V., Pisarevsky, S. A., Thrane, K. \& Vernikovsky, V. 2007. Assembly, configuration, and break-up history of Rodinia: a synthesis. Precambrian Research, in press.

Martin, D. \& Thorne, A. M. 2004. Tectonic setting and basin evolution of the Bangemall Supergroup in the northwestern Capricorn Orogen. Precambrian Research, 128, 385-409.

Miall, A. D. 1995. Collision-Related Foreland Basins. In Busby, C. J. \& Ingersoll, R. V. (eds) Tectonics of Sedimentary Basins. Blackwell Science, Cambridge, Massachusetts, 393-424.

Myers, J. S. 1990. Pinjarra Orogen. Geology and Mineral Resources of Western Australia. Geological Survey of Western Australia, Perth, 265-274.

Myers, J. S. 1993. Precambrian history of the West Australian craton and adjacent orogens. Annual Review of Earth and Planetary Sciences, 21, 453-485.

Occhipinti, S. A., Sheppard, S., Nelson, D. R., Myers, J. S. \& Tyler, I. M. 1998. Syntectonic granite in the southern margin of the Palaeoproterozoic Capricorn Orogen, Western Australia. Australian Journal of Earth Sciences, 45, 822-822.

Occhipinti, S. A. 2004. Tectonic Evolution of the Southern Capricorn Orogen, Western Australia, Curtin University of Technology.

Occhipinti, S. A. \& Reddy, S. M. 2004. Deformation in a complex crustal-scale shear zone: Errabiddy Shear Zone, Western Australia. In Alsop, G. I., Holdsworth, R. E., Mccaffrey, K. J. W. \& Hand, M. (eds) Flow Processes in Faults and Shear Zones. Geological Society, London, Special Publication, 224, 229-248.

Occhipinti, S. A., Sheppard, S., Passchier, C., Tyler, I. M. \& Nelson, D. R. 2004. Palaeoproterozoic crustal accretion and collision in the southern Capricorn Orogen: the Glenburgh Orogeny. Precambrian Research, 128, 237-255.

Pisarevsky, S. A., Wingate, M. T. D., Powell, C. M., Johnson, S. \& Evans, D. A. D. 2003. Models of Rodinia assembly and fragmentation In Yoshida, M., Windley, B. E., Dasgupta, 
S. \& (eds) Proterozoic East Gondwana: Supercontinent Assembly and Breakup. Geological Society, London, Special Publication, 206, 35-55.

Reddy, S. M., Collins, A. S., Buchan, C. \& Mruma, A. H. 2004. Heterogeneous excess argon and Neoproterozoic heating in the Usagaran Orogen, Tanzania, revealed by single grain ${ }^{40} \mathrm{Ar} /{ }^{39} \mathrm{Ar}$ thermochronology. Journal of African Earth Sciences, 39, 165-176.

Reddy, S. M. \& Occhipinti, S. A. 2004. High-strain zone deformation in the southern Capricorn Orogen, Western Australia: Kinematics and age constraints. Precambrian Research, 128, 295-314.

Rex, D. C. \& Guise, P. G. 1995. Evaluation of argon standards with special emphasis on time scale measurements. In Odin, G. S. (ed) Phanerozoic Time Scale. IUGS Subcommision on Geochronology, 21-23.

Sheppard, S., Occhipinti, S. A. \& Tyler, I. M. 2004. A 2005-1970 Ma Andean-type batholith in the southern Gascoyne Complex, Western Australia. Precambrian Research, 128, 257277.

Sheppard, S., Occhipinti, S. A. \& Nelson, D. R. 2005. Intracontinental reworking in the Capricorn Orogen, Western Australia: the 1680-1620 Ma Mangaroon Orogeny. Australian Journal of Earth Sciences, 52, 443-460.

Sherlock, S. \& Kelley, S. P. 2002. Excess argon evolution in HP-LT rocks: a UVLAMP study of phengite and K-free minerals, NW Turkey. Chemical Geology, 183, 619-636.

Song, T. \& Cawood, P. A. 2000. Structural styles in the Perth Basin associated with the Mesozoic break-up of Greater India and Australia. Tectonophysics, 317, 55-72.

Spaggiari, C. V., Wartho, J.-A. \& Wilde, S. A. 2008. Proterozoic Deformation in the Northwest of the Archean Yilgarn Craton, Western Australia. Precambrian Research, In press.

Steiger, R. H. \& Jager, E. 1977. Subcommision on Geochronology: Convention on the use of decay constants in geo- and cosmochronology. Earth and Planetary Science Letters, 36, 359-362.

Trendall, A. F. \& Cockbain, A. E. 1990. Introduction, Chapter Four: Basins. Memoir of the Geological Survey of Western Australia, 3, 291-293. 
Walter, M. R., Veevers, J. J., Calver, C. R. \& Grey, K. 1995. Neoproterozoic stratigraphy of the Centralian Superbasin, Australia. Precambrian Research, 73.

Williams, I. R. 1992. Geology of the Savory Basin, Western Australia, Western Australia Geological Survey, Bulletin, 141.

Wingate, M. T. D. \& Giddings, J. W. 2000. Age and palaeomagnetism of the Mundine Well dyke swarm, Western Australia: implications for an Australia-Laurentia connection at 755 Ma. Precambrian Research, 100, 335-357.

Wingate, M. T. D., Pisarevsky, S. A. \& Evans, D. A. D. 2002. Rodinia connections between Australia and Laurentia: no SWEAT, no AUSWUS? Terra Nova, 14, 121-128.

Wingate, M. T. D., Pirajno, F. \& Morris, P. A. 2004. Warakurna large igneous province: A new Mesoproterozoic large igneous province in west-central Australia. Geology, 32, 105108. 


\section{Figure Captions}

Figure 1: Map showing major geological features of the West Australian Craton.

Figure 2: Simplified geological map of the southern Capricorn Orogen showing major geological units. Sample locations for ${ }^{40} \mathrm{Ar} /{ }^{39} \mathrm{Ar}$ analyses from the Yilgarn craton (Narryer terrane), the Errabiddy Shear Zone and the Gascoyne Complex are shown.

Figure 3: Simplified geological map of the Errabiddy Shear Zone and northern Yilgarn craton showing summary of ${ }^{40} \mathrm{Ar} /{ }^{39} \mathrm{Ar}$ ages of biotite and muscovite. Note that age data from CV065 and SO2_16A/C are not shown. Ages represent interpretation after analysis of compositional, excess Ar and Ar loss in detailed by Occhipinti (2004).

Figure 4: Age - grainsize relationships for muscovite and biotite analysed by infrared laser total grain fusion. Samples are from the Gascoyne Complex (a-d), the western Errabiddy Shear Zone (e-l) and eastern Errabiddy Shear Zone (m-n). n = number of analyses for each sample. Where analyses plot over each other the number of analyses is noted in parentheses besides the analysis symbol. Note that error bars are often small and are hidden behind the symbol used to represent the analyses.

Figure 5: Histograms summarising the frequency of ages measured on muscovite and biotite by total grain total fusion of single and occasional multiple grain fusion of small grains (usually $<200 \mu m$ ) for different regions of the south Capricorn region. Distributions were calculated using a bin size of 20 Ma.

Figure 6: Single and multiple grain IR-laser step-heated data from samples from the Central and Southern Gascoyne Complex, the Errabiddy Shear Zone and the Yilgarn Craton (Narryer Terrane).

Figure 7: Summary of palaeocurrent data from the Sunbeam Group of the Neoproterozoic Officer Basin (modified after Williams, 1992). Arrows show the direction of flow inferred from palaeocurrent indicators and, along with petrological evidence, indicate provenance of sediments from the eroding Edmundian Orogeny. 
Figure 8: Simplified model for development of the western margin of the West Australian Craton, during the Mesoproterozoic and Neoproterozoic based on data presented here and by Fitzsimons (2003). 1150 Ma: deposition of sediments now preserved in the proto-Mullingarra and Northampton Complexes. 1080 Ma: metamorphism of these sediments and continuing dextral transpressional deformation along the western part of Western Australia lead to northward migration of the Mullingarra and Northampton complexes to their current positions. 950 Ma: Continuing deformation on the western margin of the West Australian Craton caused the initiation of the Edmundian Orogeny in the Capricorn Orogen. Thermal effects associated with collisional activity give rise to resetting of Ar isotopes in mica. Increasing uplift leads to increased erosion of the evolving orogen and led to deposition of sedimentary detritus into the Neoproterozoic Officer Basin.

\section{Tables}

Table 1: Summary of ${ }^{40} \mathrm{Ar} /{ }^{39} \mathrm{Ar}$ results reported in detail in the supplementary data. Bolded ages are those interpreted as the best estimates of isotopic closure based on detailed analysis of the composition, grains size, Ar relationships by Occhipinti (2004). WM= white mica (muscovite); B= biotite; IRF= Infrared fusion; IRSH= Infrared step heated; SGA= single grain analyses; MGA= multiple grain analyses (number of grains indicated in parentheses). All ages are quoted at $1 \sigma$. For sample 142900 mean ages were not calculated because the age range was considerable. 


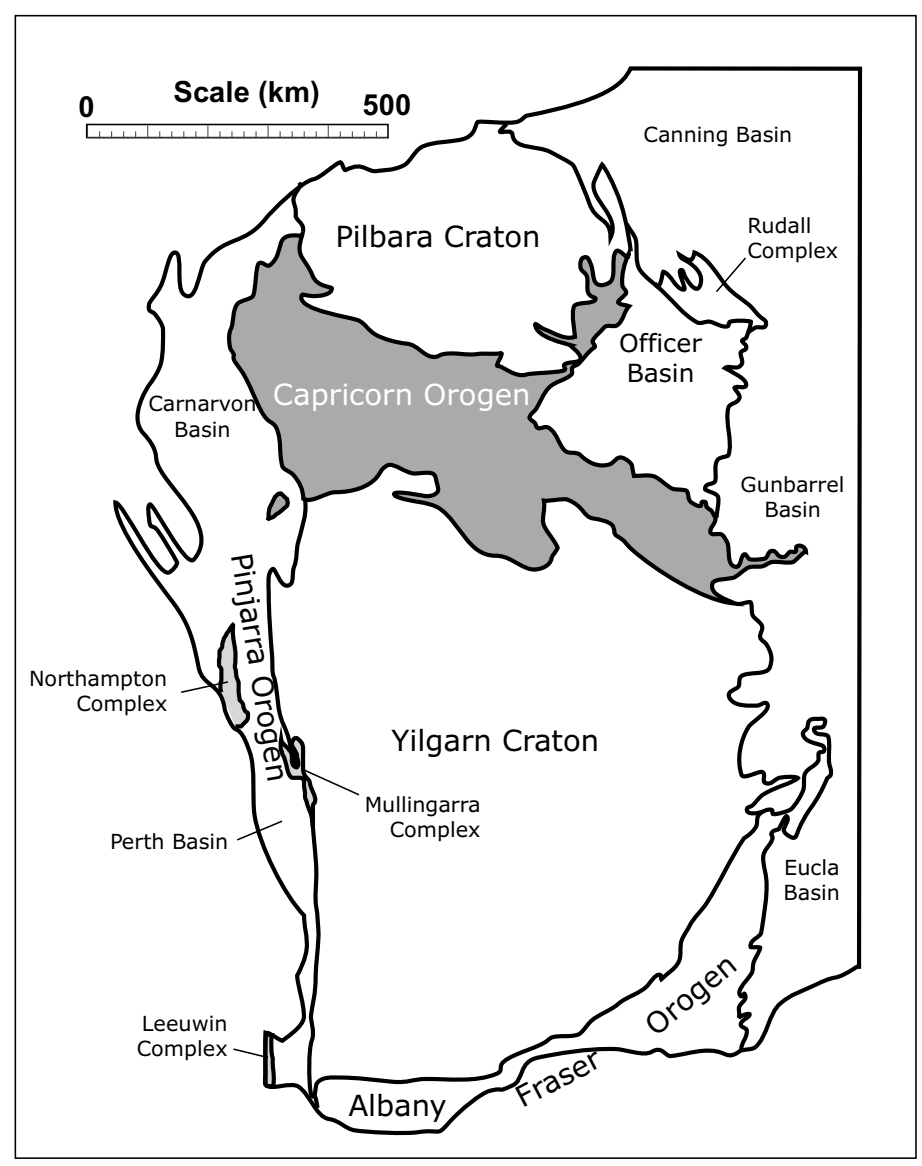

Occhipinti \& Reddy 2007 / Figure 1 


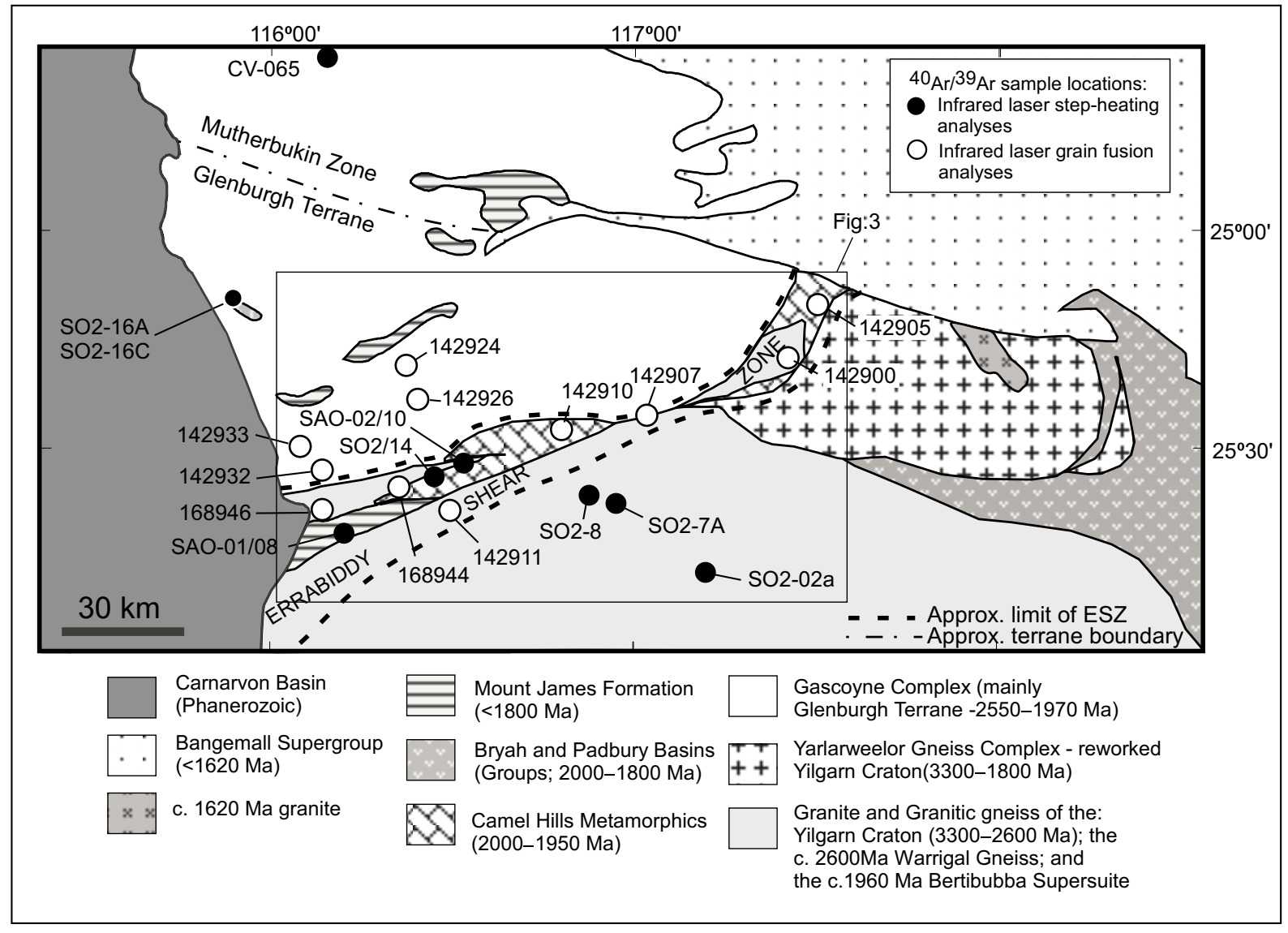

Occhipinti \& Reddy: Figure 2 


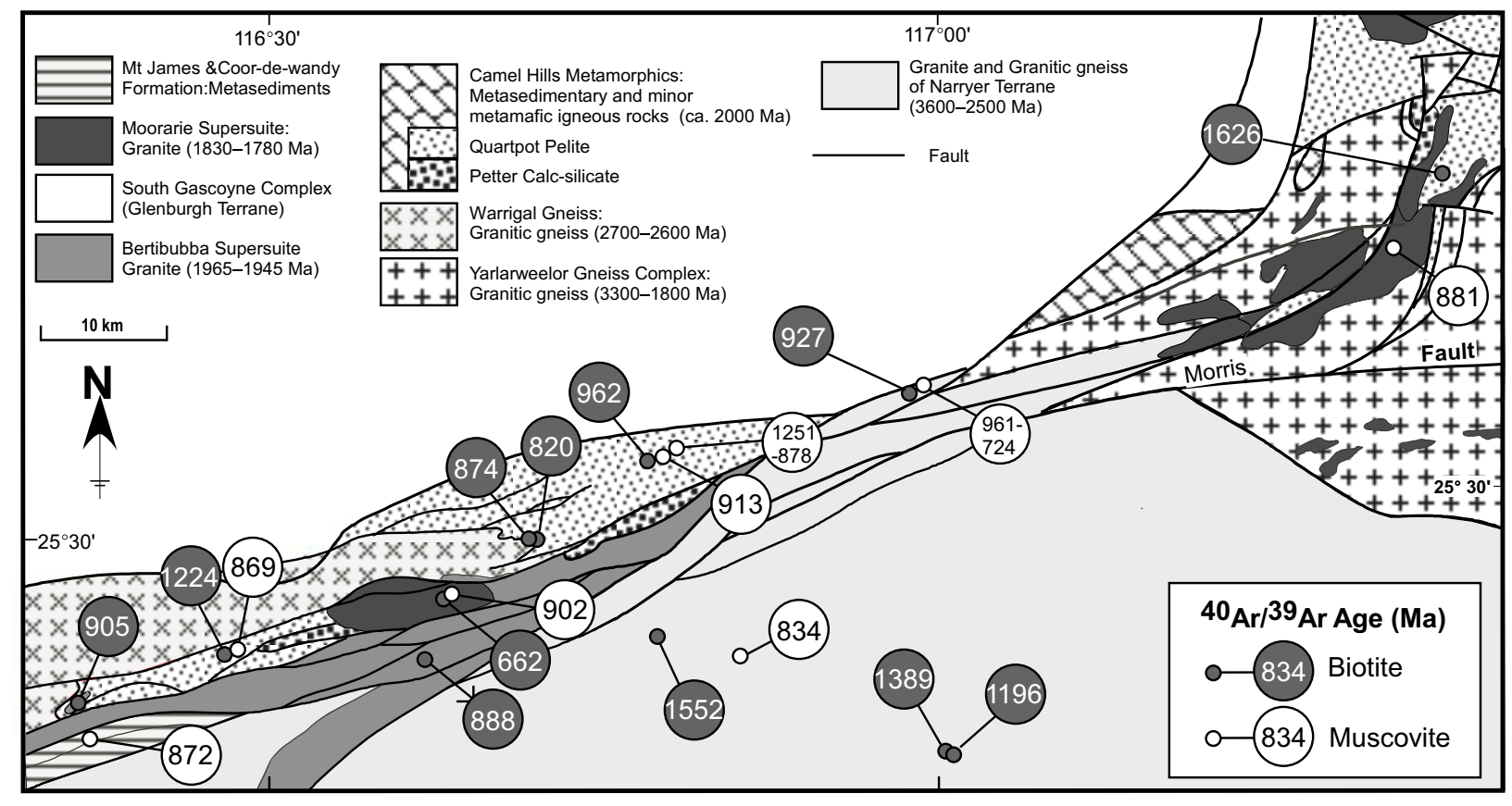

Occhipinti \& Reddy: Figure 3 

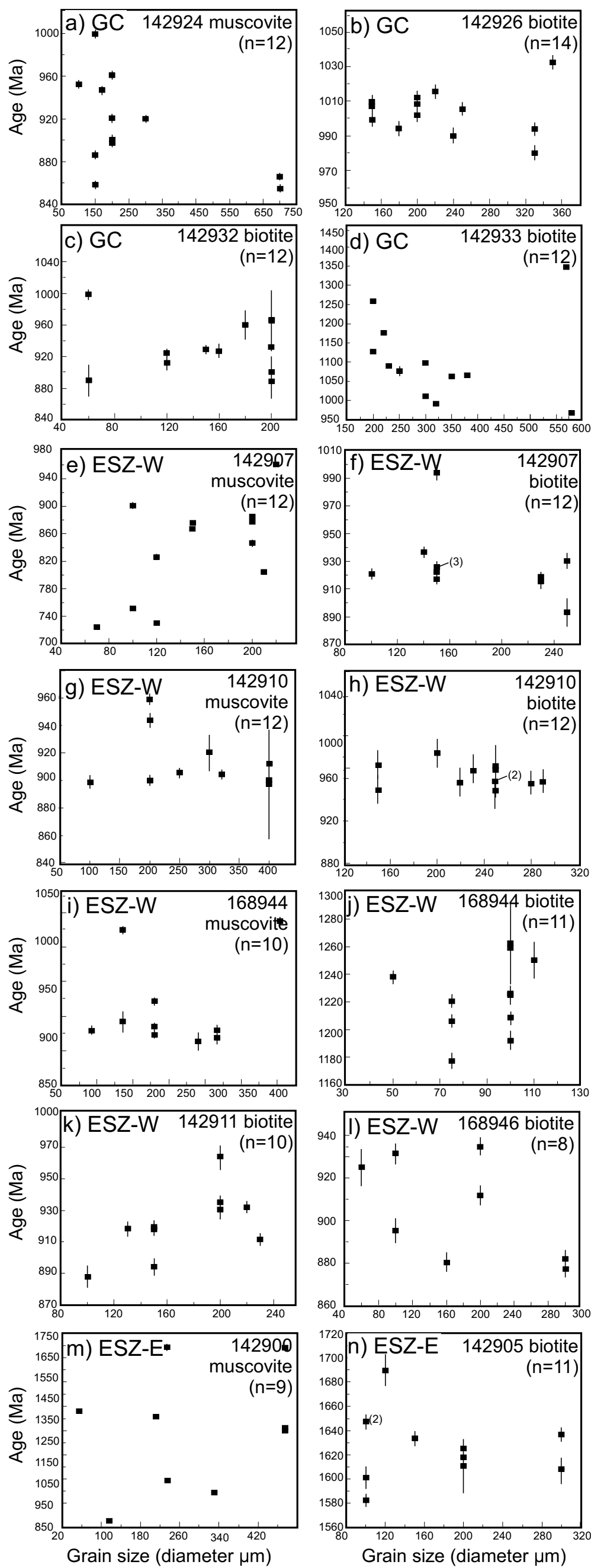

Occhipinti \& Reddy 2007/ Figure 4 

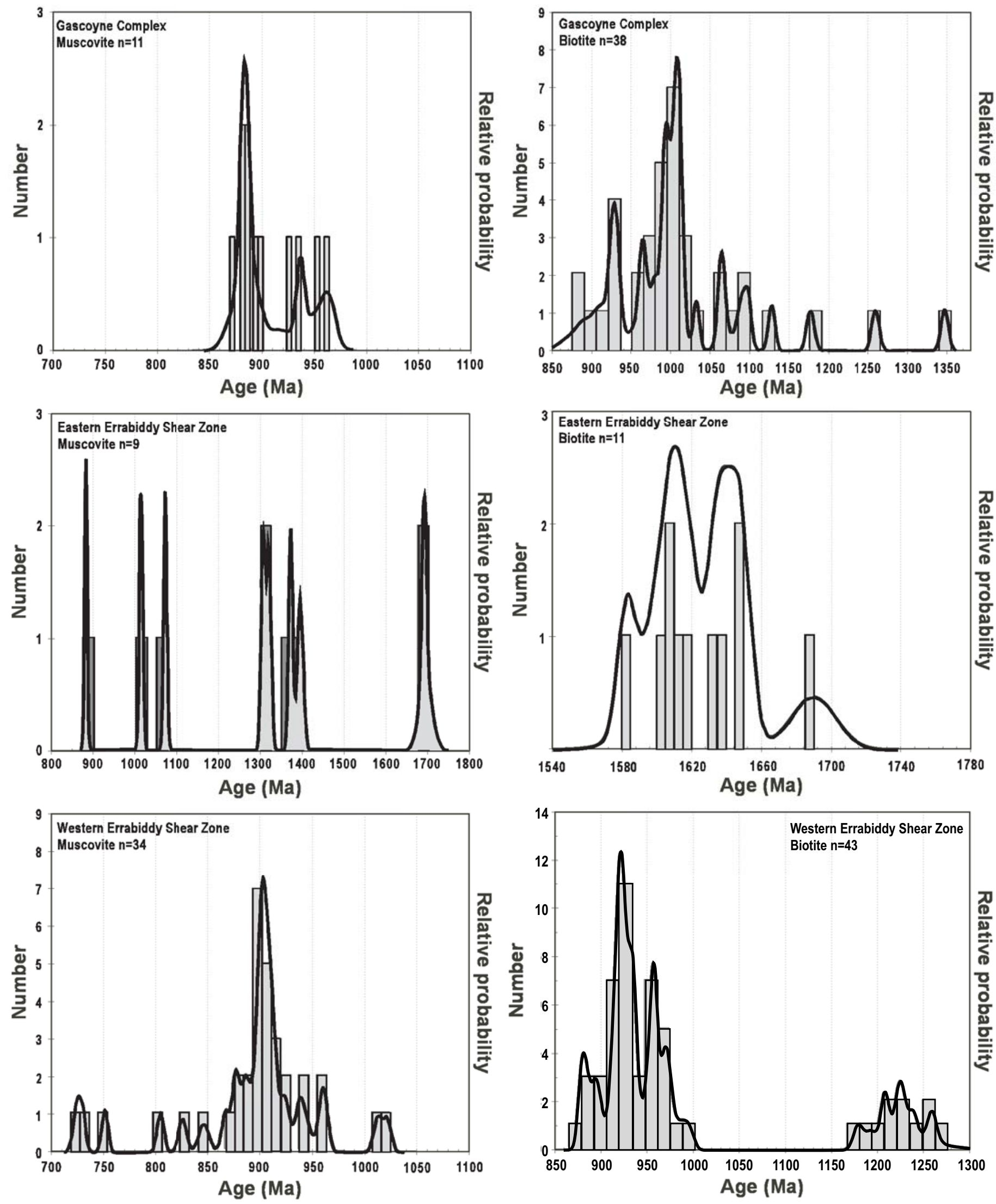

Occhipinti \& Reddy 2007 / Fig 5 

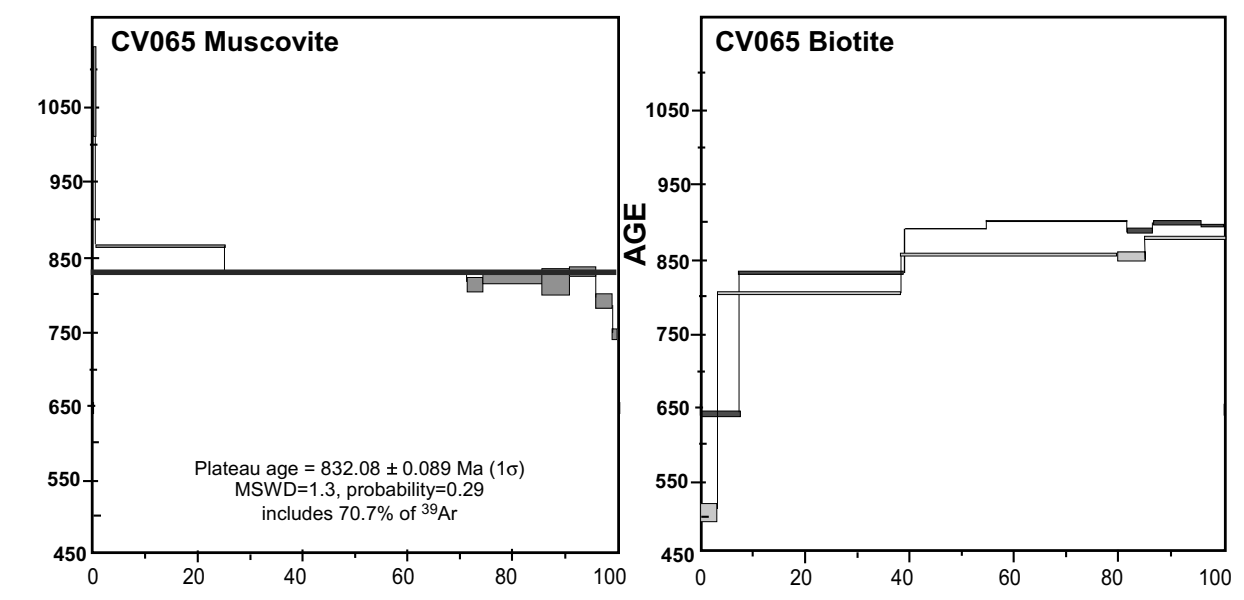

\section{Central Gascoyne Complex}
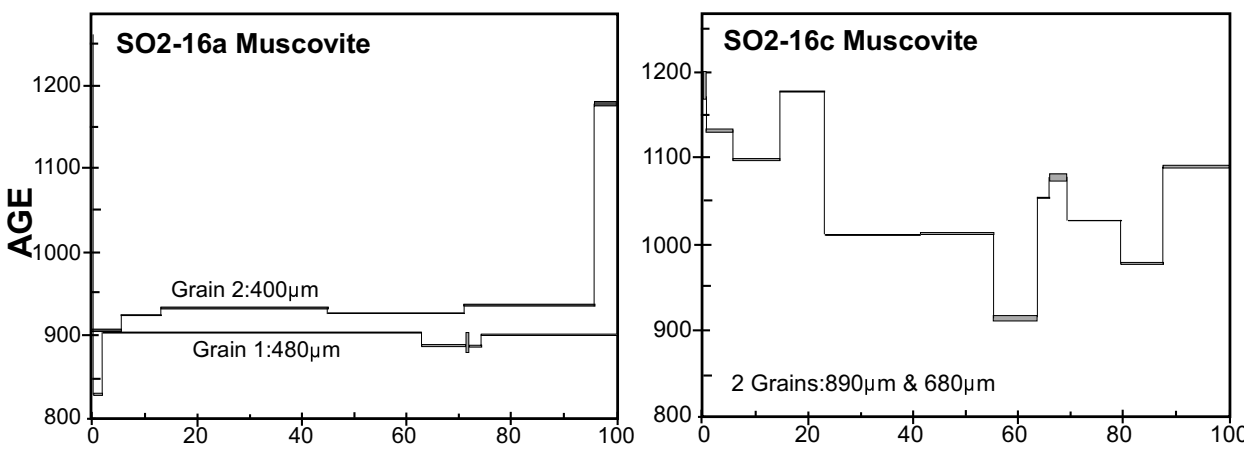

Southern Gascoyne Complex (Glenburgh Terrane)
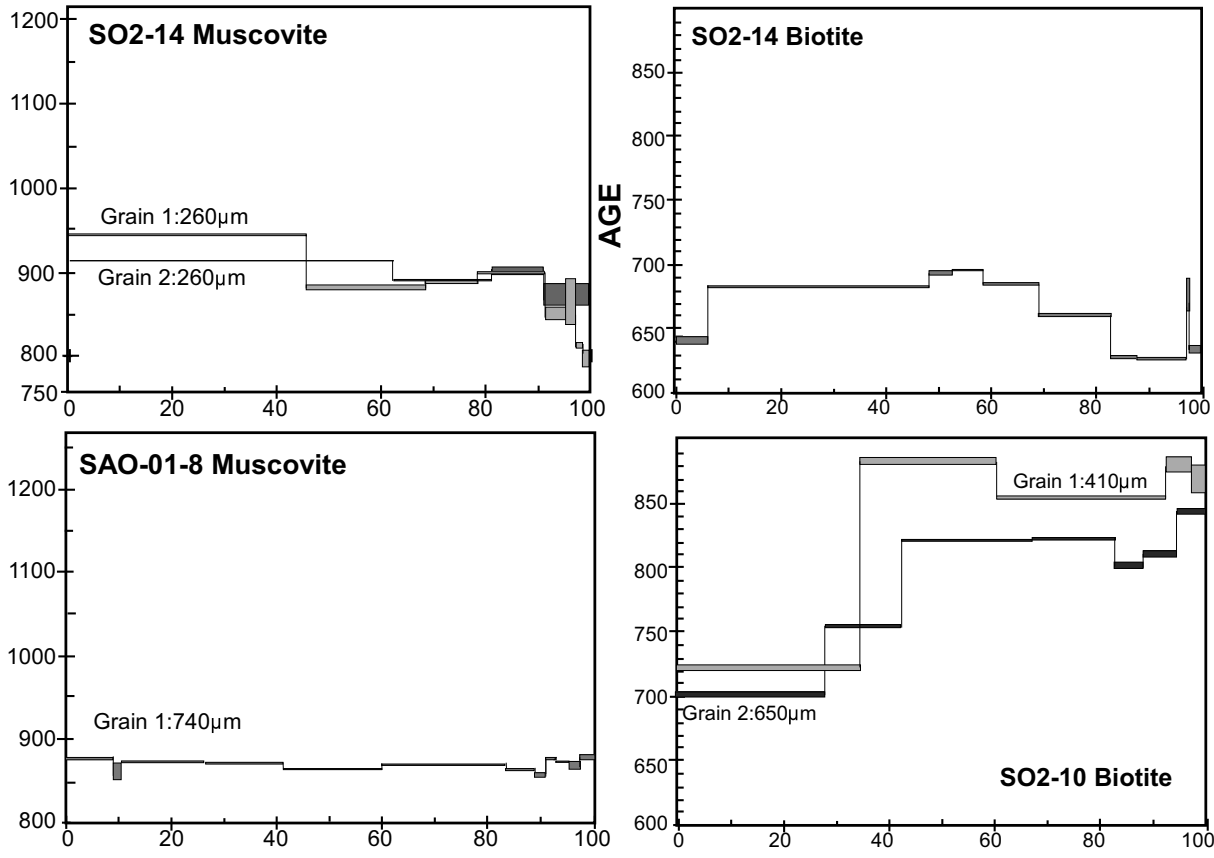

Errabiddy Shear Zone
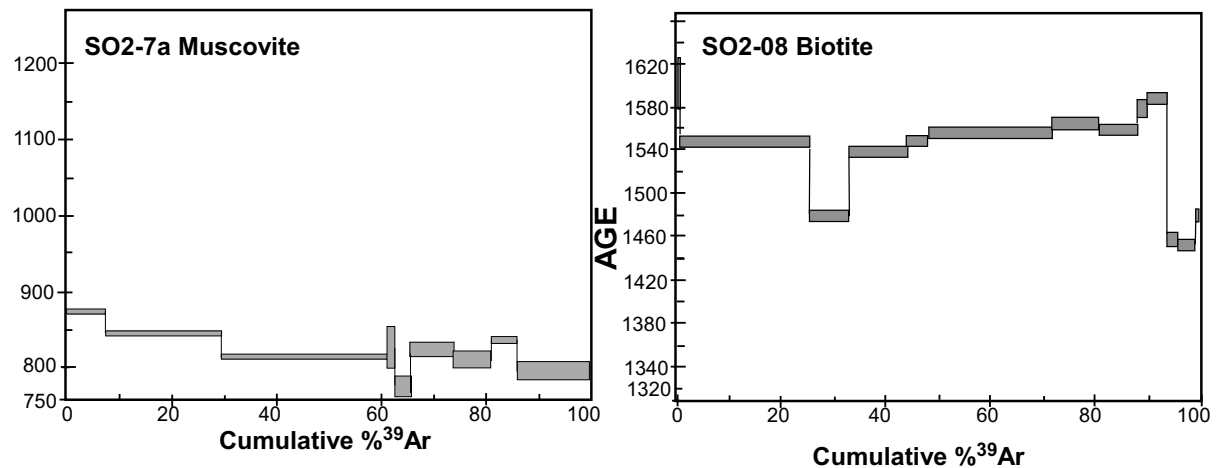

Narryer Terrane

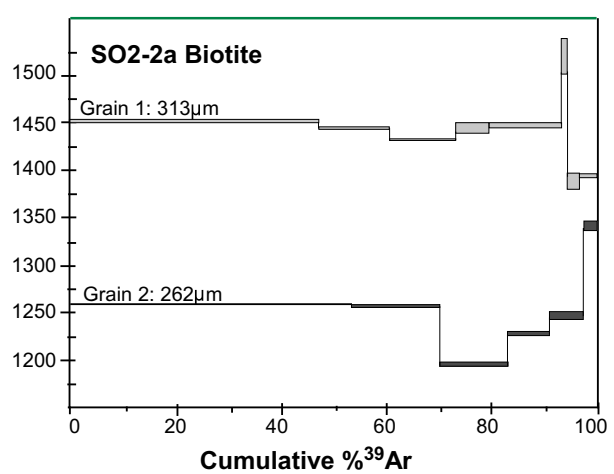




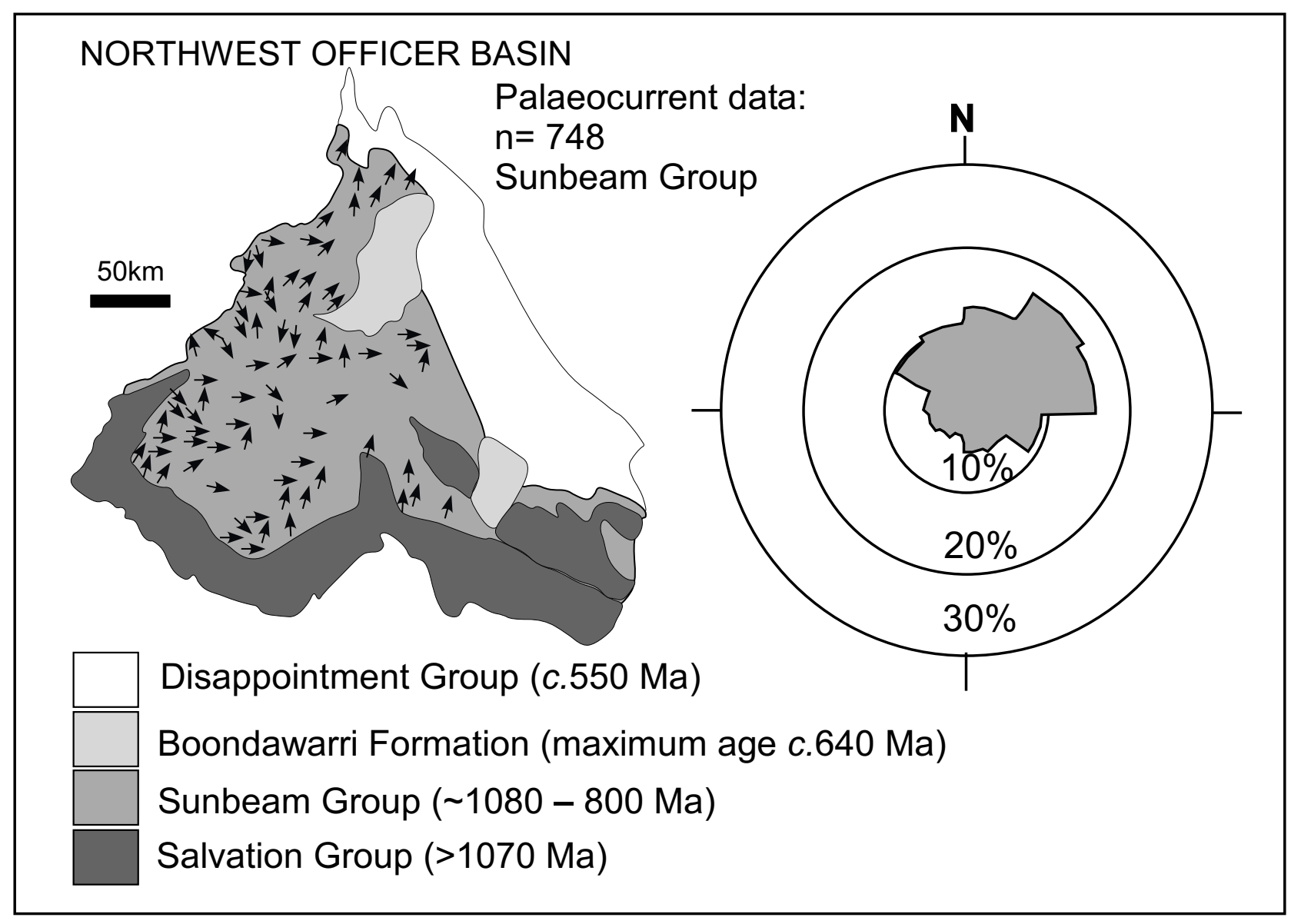

Occhipinti \& Reddy (2007) / Figure 7 


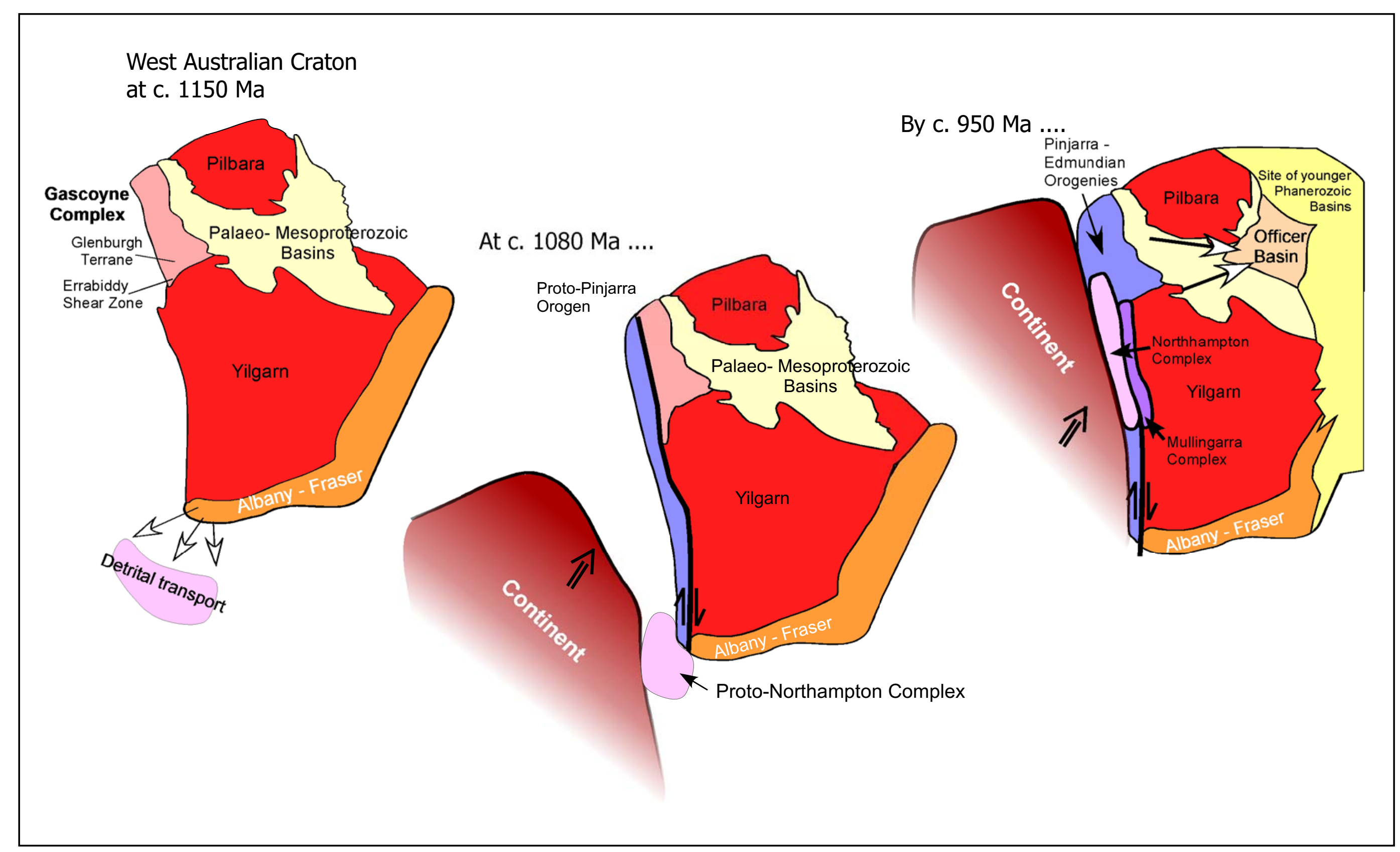




\begin{tabular}{|c|c|c|c|c|c|c|c|c|c|c|}
\hline Area & $\begin{array}{l}\text { Sample } \\
\text { name }\end{array}$ & Mineral & $\begin{array}{l}\text { Analytical } \\
\text { Method }\end{array}$ & $\begin{array}{c}\% \text { Atmospheric Ar } \\
\text { (range) }\end{array}$ & $\begin{array}{c}\text { Weighted } \\
\text { mean age } \\
\text { (Ma) }\end{array}$ & $\begin{array}{l}\text { Unweighted } \\
\text { mean age } \\
\text { (Ma) }\end{array}$ & $\begin{array}{c}\text { Plataeux ages, } \\
\text { unweighted mean ages } \\
\text { using select data (Ma) }\end{array}$ & $\begin{array}{l}\text { Max age } \\
\text { (Ma) }\end{array}$ & $\begin{array}{l}\text { Min Age } \\
\text { (Ma) }\end{array}$ & $\begin{array}{c}\text { Grain } \\
\text { diameter } \\
(\mu \mathrm{m})\end{array}$ \\
\hline \multirow{3}{*}{$\begin{array}{l}\text { Narryer } \\
\text { Terrane } \\
\text { (Yilgarn } \\
\text { Craton) }\end{array}$} & SO2-2a & B GR1 & IRSH & $0-1.60$ & $1434 \pm 2$ & $1440 \pm 38$ & & $1591 \pm 20$ & $1389 \pm 10$ & 313 \\
\hline & & $\begin{array}{c}\text { B GR2 } \\
\text { WM }\end{array}$ & IRSH & $0-1.0$ & $\begin{array}{c}1249 \pm 2 \\
834 \pm 2\end{array}$ & & & $\begin{array}{c}1341 \pm 6 \\
874 \pm 5\end{array}$ & $\begin{array}{l}\mathbf{1 1 9 6} \pm 5 \\
773+15\end{array}$ & $\begin{array}{l}262 \\
332\end{array}$ \\
\hline & $\begin{array}{l}\text { SO2-7a } \\
\text { SO2-08 }\end{array}$ & $\begin{array}{c}\text { WM } \\
\text { B }\end{array}$ & IRSH & $0-1.8$ & $\begin{array}{c}834 \pm 2 \\
1532 \pm 2\end{array}$ & $\begin{array}{c}\mathbf{8 3 4} \pm \mathbf{2 1} \\
1536 \pm 49\end{array}$ & $1552 \pm 30\left(93.3 \%{ }^{39} \mathrm{Ar}\right)$ & $\begin{array}{c}874 \pm 5 \\
1604 \pm 25\end{array}$ & $\begin{array}{l}773 \pm 15 \\
1452 \pm 6\end{array}$ & $\begin{array}{c}332 \\
578,260\end{array}$ \\
\hline \multirow{2}{*}{\multicolumn{11}{|c|}{$\begin{array}{l}\text { Errabiddy } \\
\text { Shear Zone }\end{array}$}} \\
\hline & & & & & & & & & & \\
\hline \multirow[t]{2}{*}{ East } & 142900 & WM & IRF & $0.03-6.53$ & N/A & N/A & & $1694 \pm 16$ & $881 \pm 4$ & 050-200 \\
\hline & 142905 & B & IRF & $0-5.01$ & $1623 \pm 2$ & $1626 \pm 28$ & & $1690 \pm 13$ & $1582 \pm 5$ & 050-150 \\
\hline \multirow[t]{15}{*}{ West } & 142907 & B & IRF & $1.47-14.01$ & $927 \pm 1$ & $927 \pm 23$ & & $994 \pm 6$ & $893 \pm 10$ & 050-125 \\
\hline & 142907 & WM & IRF & $0-1.51$ & $826 \pm 1$ & $837 \pm 70$ & & $961 \pm 4$ & $724 \pm 3$ & $100-200$ \\
\hline & 142910 & B & IRF & $1.78-9.11$ & $961 \pm 1$ & $962 \pm 10$ & & $984 \pm 6$ & $973 \pm 5$ & 075-145 \\
\hline & 142910 & WM & IRF & $0-5.81$ & $912 \pm 1$ & $913 \pm 20$ & & $959 \pm 4$ & $888 \pm 5$ & $050-200$ \\
\hline & 142911 & B & IRF & $0-12.22$ & $921 \pm 1$ & $921 \pm 20$ & & $964 \pm 8$ & $\mathbf{8 8 8} \pm 7$ & 050-115 \\
\hline & 168944 & B & IRF & $1.72-7.09$ & $1220 \pm 2$ & $1224 \pm 26$ & & $1263 \pm 30$ & $1178 \pm 5$ & 050-110 \\
\hline & 168944 & WM & IRF & $0-2.43$ & $941 \pm 2$ & $931 \pm 44$ & & $1021 \pm 4$ & $896 \pm 9$ & 050-200 \\
\hline & 168946 & B & IRF & $2.56-10.87$ & $902 \pm 2$ & $905 \pm 22$ & & $935 \pm 4$ & $877 \pm 4$ & 030-150 \\
\hline & SAO-01/67 & WM & & & & & & & & \\
\hline & $\mathrm{SO} / 10$ & B GR1 & IRSH & $0-40.08$ & $828 \pm 2$ & $843 \pm 61$ & $874 \pm 11\left(65.6 \%{ }^{39} \mathrm{Ar}\right)$ & $882 \pm 7$ & $722 \pm 4$ & 410 \\
\hline & & B GR2 & & $2.90-23.9$ & $789 \pm 1$ & $794 \pm 46$ & $820 \pm 14\left(52.5 \%{ }^{39} \mathrm{Ar}\right)$ & $701 \pm 3$ & $844 \pm 4$ & 650 \\
\hline & $\mathrm{SO} 2 / 14$ & WM GR1 & IRSH & $0-13.56$ & $884 \pm 2$ & $866 \pm 43$ & $901 \pm 24\left(91.7 \%{ }^{39} \mathrm{Ar}\right)$ & $942 \pm 4$ & $801 \pm 7$ & 260 \\
\hline & & WM GR2 & & $0-5.92$ & $902 \pm 2$ & $896 \pm 15$ & $903 \pm 10\left(91.59 \%{ }^{39} \mathrm{Ar}\right)$ & $915 \pm 4$ & $875 \pm 13$ & 260 \\
\hline & & B & IRSH & 4.67-10.924 & $662 \pm 1$ & $662 \pm 26$ & & $696 \pm 3$ & $627 \pm 3$ & 650 \\
\hline & SAO-01/08 & WM & IRSH & $0-2.16$ & $873 \pm 1$ & $872 \pm 6$ & & $881 \pm 5$ & $861 \pm 5$ & 740 \\
\hline \multirow{12}{*}{$\begin{array}{l}\text { Gascoyne } \\
\text { Complex }\end{array}$} & 142924 & WM & IRF & $0.09-1.70$ & $911 \pm 1$ & $914 \pm 43$ & & $999 \pm 4$ & $855 \pm 3$ & 050-350 \\
\hline & 142926 & B & IRF & $3.56-12.04$ & $1001 \pm 1$ & $1001 \pm 16$ & & $1032 \pm 4$ & $964 \pm 4$ & 075-175 \\
\hline & 142932 & B & IRF & $0-8.68$ & $936 \pm 2$ & $933 \pm 33$ & & $999 \pm 6$ & $889 \pm 21$ & $100-200$ \\
\hline & 142932 & WM & IRF & $0-2.61$ & $898 \pm 2$ & $906 \pm 30$ & & $963 \pm 7$ & $880 \pm 4$ & $150-200$ \\
\hline & 142933 & B & IRF & $0.10-4.24$ & $1102 \pm 1$ & $1106 \pm 105$ & & $1176 \pm 5$ & $967 \pm 6$ & $60-290$ \\
\hline & SO2-16A & WM GR1 & IRSH & $0.13-13.29$ & $886 \pm 2$ & $940 \pm 137$ & $895 \pm 7\left(98.4 \%{ }^{39} \mathrm{Ar}\right)$ & $1269 \pm 16$ & $932 \pm 3$ & 480 \\
\hline & & GR2 & & $0-1.04$ & $950 \pm 2$ & $966 \pm 93$ & $925 \pm 10\left(95.5 \%{ }^{39} \mathrm{Ar}\right)$ & $1174 \pm 5$ & $906 \pm 4$ & 400 \\
\hline & SO2-16C & WM & IRSH & 0-9.05 & $1045 \pm 1$ & $1061 \pm 76$ & & $1182 \pm 17$ & $914 \pm 4$ & 890 \\
\hline & & & & & & & & & & 620 \\
\hline & CV-065 & WM & IRSH & $0-15.97$ & $834 \pm 2$ & $845 \pm 85$ & 832 \pm 1 (plateau age) & $1071 \pm 60$ & $750 \pm 8$ & Not measured \\
\hline & & B GR1 & IRSH & $0-26.97$ & $836 \pm 2$ & $781 \pm 140$ & $865 \pm 12\left(61.9 \%^{39} \mathrm{Ar}\right)$ & $881 \pm 4$ & $506 \pm 12$ & Not measured \\
\hline & & B GR2 & IRSH & $0-19.32$ & $852 \pm 2$ & $850 \pm 87$ & $895 \pm 6\left(61.1 \%{ }^{39} \mathrm{Ar}\right)$ & $903 \pm 4$ & $831 \pm 4$ & Not measured \\
\hline
\end{tabular}

